Review Article

\title{
Cocoa Farming System in Indonesia and Its Sustainability Under Climate Change
}

\author{
Julian Witjaksono*, Asmin \\ Indonesia

\section{Email address:} \\ julian_witjaksono@yahoo.com (J. Witjaksono) \\ ${ }^{*}$ Corresponding author
}

The Assessment Institute for Agricultural Technology, the Indonesia's Agency for Agriculture Research and Development, Southeast Sulawesi,

\section{To cite this article:}

Julian Witjaksono, Asmin. Cocoa Farming System in Indonesia and Its Sustainability Under Climate Change. Agriculture, Forestry and Fisheries. Vol. 5, No. 5, 2016, pp. 170-180. doi: 10.11648/j.aff.20160505.15

Received: July 12, 2016; Accepted: July 28, 2016; Published: September 7, 2016

\begin{abstract}
The Indonesian cocoa sector has experienced tremendous growth in the past twenty five years with massive growth, driven by rapid expansion of smallholder farmer participation. Cocoa production provides the main source of income of millions smallholder farmers and their families in Indonesia. Smallholders contribute more than ninety percent of national production; the remainder comes from state-owned plantations and private estates. In parts of Indonesia, cocoa is responsible for the opening up of primary forests and the establishment of settlements in these previously forested areas. Cocoa intensification system, which increases the fragmentation of primary forests and is considered agriculturally unsustainable, is becoming common in Indonesia. This paper presents the synthesis that resulted from this review as well as the researcher's critical appraisal of the state of the research field of intensification system and its effect under climate change which the objective remaining stakeholder relevant to the sustainable intensification of farming practices of the poor smallholder farmers in Indonesia.
\end{abstract}

Keywords: Cocoa, Smallholders, Climate Change, Sustainable Intensification

\section{Introduction}

Agriculture is a diverse economic sector that produces food, fibre, material and energy commodities. In most regions, agricultural productivity is directly dependent on weather and climate conditions - more so than any other major economic sector. Climate change is a significant driver of change for food security [1] because its threatens food production and its stability as well as other aspects of food system such as storage, food access and utilization [2]. Therefore, agriculture must change to meet the rising demand, to contribute more effectively to the reduction of poverty and malnutrition, and to become ecologically more sustainable. Changes in extremes have been observed since 1950, and there is an evidence that some of these changes are a result of anthropogenic influences, although attribution of single extreme events to these influences remains challenging [3]. It is extremely likely that human influence has been the dominant cause of the observed warming since the mid-20th century. Changes in temperature and precipitation associated with continued emissions of greenhouse gases will bring changes in land suitability and crop yields [3].

In Indonesia, agricultural activities (beyond forestry and fishery) in the rural areas absorbed $30.27 \%$ employment in Indonesia despite its $10.26 \%$ contribution to the Indonesia GDP in 2014 [4]. Meanwhile about $11.47 \%$ of Indonesian population lives under poverty line and $66 \%$ of these live in the rural areas mainly in Java and and Sumatera [5]. Moreover, according to Indonesian's Ministry of Agriculture in the year of 2015 the contribution of crop estate (oil palm, cocoa and coffee) to the Indonesia GDP is about $5.79 \%$ in 2014. Therefore, agricultural sector still plays an important role to eliminate poverty in rural areas. The Indonesian cocoa sector has experienced tremendous growth in the past 25 years with massive growth, driven by rapid expansion of smallholder farmer participation. Indonesia is now the third biggest cocoa producer (777,750 MT/year) [6] after Cote d'Ivoire and Ghana, with about a $15 \%$ share of total world cocoa bean 
production. Cocoa has been cultivating in Indonesia over 1.5 million hectares, generating over $\$ 1.2$ billion in exports annually. Thus, the cocoa bean is one of the most important agricultural export products of Indonesia. Cocoa production provides the main source of income for over 1,400,000 smallholder farmers and their families in Indonesia and they contribute $93 \%$ of national production. The majority (71\%) of Indonesian cocoa production is concentrated on Sulawesi island. The remaining cocoa production areas are situated on North Sumatra, West Java and Papua, with some small-scale production areas in Bali, Flores, and other islands.

Figure 1 below describes it is clear that Cote d'Ivoire is the largest cocoa production in the world. Moreover, Indonesia is the third largest producing cocoa after Ghana in 2012 and 2013. However, it is surprisingly that we found Indonesia is the world's second largest cocoa production between in the year of 2005 and 2011 then Ghana was leading of Indonesia as the world's second largest from 2012 to 2013. This is indicates even the cocoa production in Indonesia has increased gradually since 2011 but Ghana has produced more cocoa beans than Indonesia. Therefore, now Ghana is the world's second largest cocoa production. Meanwhile the cocoa production of Cote d'Ivoire is remain stable between 2003 and 2013. Data showed that cocoa export from Indonesia's main cocoa growing region - the island of Sulawesi - declined 56 percent (year-on-year) to 1,719 metric tons in April 2015 on the back of weak weather conditions and diseases disturbing the cocoa trees. These conditions have been hampering Indonesian supplies for several years now. Despite efforts, the Indonesian government has failed to boost production. This may cause that Indonesia's cocoa bean export in 2015 falls below pre-2001 levels [7].

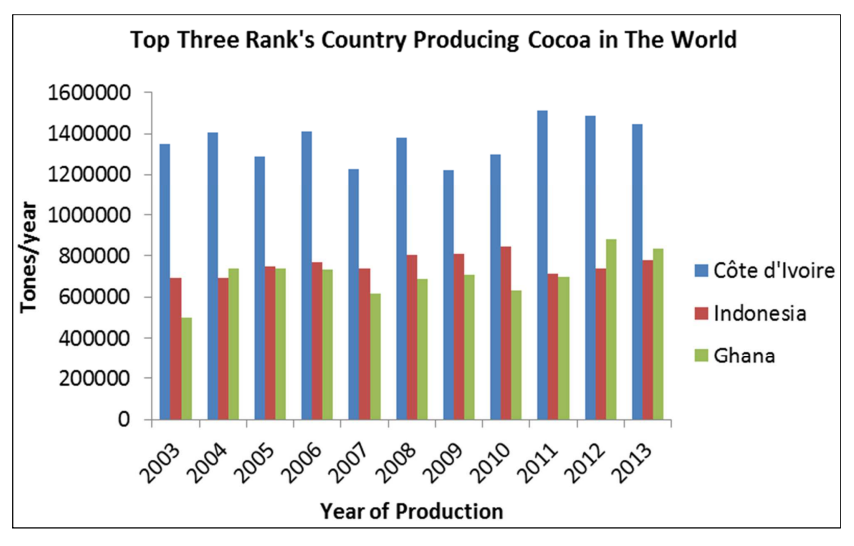

Source: [7]

Figure 1. The Top Three Cocoa-Producing Countries between 2003 and 2013.

This paper objectives were addressed by performing a systematic review of both academic, scientific and grey literature elaborating on sustainable intensification of cocoa production and climate change. This paper presents the synthesis that resulted from this review as well as the researcher's critical appraisal of the state of the research field This synthesis considers the possible impacts of changes in climate variability on agricultural system which effects on cocoa production in terms of cocoa growth and cocoa yield under different future climate conditions. Then briefly review some of sustainable agricultural systems at a range of scales. After, this paper concludes with a recommendation for a sustainable intensification on cocoa farming system to enable farmers in the tropics as well as Indonesia to address climate variability and extreme events in the future.

\section{Current Situation of Cocoa Farming System}

One of the consequences of improved standards of living in the emerging countries, such as India, China, Brazil and Russia, will be a 3\% annual increase in demand for cocoa by 2020, according to the International Cocoa Organization (ICCO). At the same time, global production, which stands at around 4 million tons per year, will grow less quickly, creating a gap between supply and demand. Experts predict that by 2020-2025, 1 million additional tons of cocoa will be required to meet demand. There is therefore a high risk of a shortage by 2030 and of a 500 or $600 \%$ increase in cocoa prices [8]. To prevent this, there is an urgent need to increase production in the long term. The World Cocoa Foundation stated that annual increase in global demand for cocoa has been three percent per year, for the past hundred years. It is estimated that global cocoa demand will increase by similar levels in the coming years and, as such, puts Indonesia in a potentially fortunate position as the country is one of the largest producers and exporters of this commodity.

However, the country is facing difficulties in increasing cocoa's important role in the economic development of Indonesia. Around 90 percent of Indonesia's cocoa output is produced by smallholders who lack the financial support to optimize production capacity, resulting in declining productions due to aging trees, diseases, and floods. Moreover, because of the recent promising perspectives of the palm oil and rubber industries, some cocoa growers have shifted their focus towards those commodities, causing that the current 1.5 million hectares of cocoa plantations may decline further in the coming years. Indonesian cocoa farmers have been grappling with disappointing harvests in recent years due to crop diseases and pests as well as adverse weather. This situation could get worse, as experts predict that climate change could cause prolonged dry periods and more extreme rainfall in the wet season. Therefore, both the quantity and quality of Indonesian beans are very low. Per-hectare yields have fallen in recent years to around $500-700 \mathrm{~kg} /$ hectare, far below a potential yield of up to $1,500 \mathrm{~kg} /$ hectare. The main problem is that many cacao trees have passed their most productive age, but farmers typically lack the capital for wide-scale rejuvenation. Smallholder farmers work more than $90 \%$ of Indonesia's cocoa cultivation area of around 1.6 million hectares, with the rest shared between state-owned and private plantation companies [9]. Typically land holding less than one hectare, smallholder farmers lose out on economies of scale because it makes little sense for them to introduce 
sophisticated equipment. They also often employ poor farming methods and lack of knowledge on pest control. In some areas, productivity has decreased significantly. Therefore, many farmers have switched cocoa planting area to rubber or oil palm.

\section{Factors Influencing Climate Change and Its Effect on Cocoa Performance}

Climate change, according to IPCC usage refers to a change in the state of the climate that can be identified (e.g. using statistical tests) by changes in the mean and/or the variability of its properties, and that persists for an extended period, typically decades or longer. It refers to any change in climate over time, whether due to natural variability or as a result of human activity [10]. Human influence has been detected in warming of the atmosphere and the ocean, in changes in the global water cycle, in reductions in snow and ice, in global mean sea level rise, and in changes in some climate extremes. According to IPCC report in 2014, it is extremely likely that, human influence has been the dominant cause of the observed

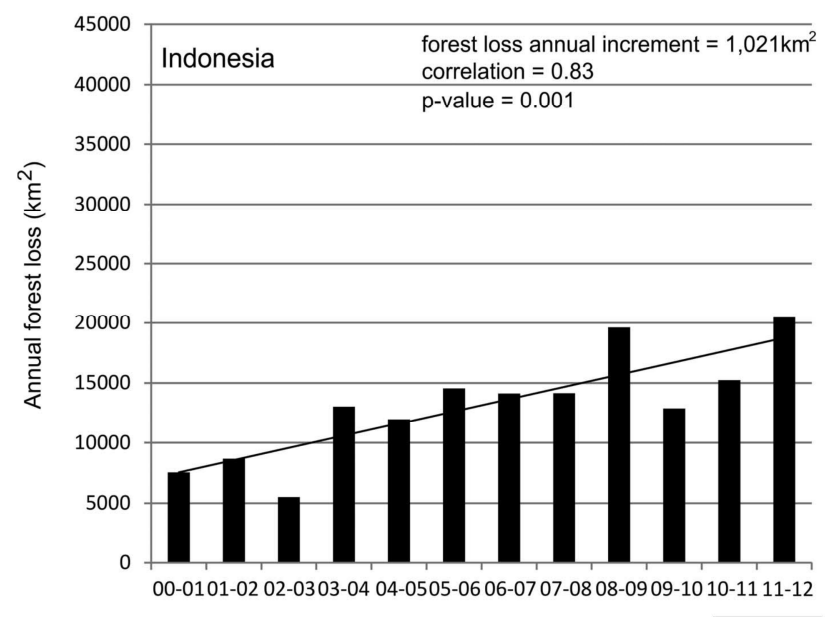

warming since the mid-20th century. Agriculture (as the human activities) in the humid tropics is both highly vulnerable to climate change and contributes to it, since the related clearing of rainforests releases high amounts of greenhouse gases [11]. Studied by IPCC in 2007 revealed that deforestation and conversion of forest to agriculture contribute $17.4 \%$ of global greenhouse gas emissions.

Indonesia has become the world's worst deforester. The country apparently cut down 840,000 hectares of forest in 2012 , on average increasing primary forest loss by around 498,000 hectares a year, 37\% of Indonesia's GHG emissions stem from deforestation. Moreover, Indonesia exhibited the largest increase in forest loss $\left(1,021 \mathrm{~km}^{2}\right.$ per year), with a low of under $10,000 \mathrm{~km}^{2}$ per year from 2000 through 2003 and a high of over $20,000 \mathrm{~km}^{2}$ per year in 2011 to 2012 [12]. However, Brazilian deforestation, of all countries globally, Brazil exhibited the largest decline in annual forest loss, with a high of over 40,000 $\mathrm{km}^{2}$ per year in 2003 to 2004 and a low of under $20,000 \mathrm{~km}^{2}$ per year in 2010 to 2011 [13]. The converging rates of forest disturbance of Indonesia and Brazil are shown in Figure 2.

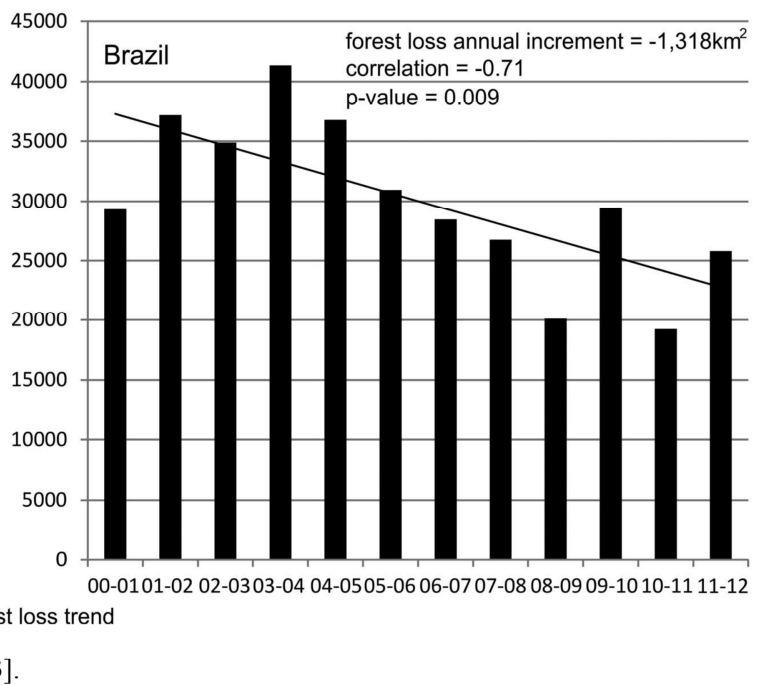

Figure 2. Annual forest loss totals for Brazil and Indonesia from 2000 to 2002. (The forest loss annual increment is the slope of estimated trend line of change in annual forest loss).

Forests are the largest terrestrial store of carbon and deforestation is the third-largest source of greenhouse gas emissions after coal and oil. Deforestation causes $15 \%$ of global greenhouse gas emissions. Of these, carbon dioxide emissions represent up to one-third of total carbon dioxide emissions released because of human causes [14]. The carbon emissions resulting from Indonesia's rapid deforestation account for around $6 \%$ to $8 \%$ of global emissions. This huge carbon foot print from forest destruction has made non-industrialized Indonesia the third-largest global greenhouse gas emitter, behind only the U.S. and China [15]. Moreover, deforestation is the second largest anthropogenic (human-caused) source of carbon dioxide to the atmosphere, ranging between 6 percent and 17 percent [16]. A recent study estimates that 11.45 Mha of deforestation occurred in
Indonesia from 2000 to 2010 , resulting in $8.59 \mathrm{GtCO}_{2} \mathrm{e}$ of emissions from deforestation and peat land degradation. Of this total, 2.27 Mha (19.9\%) of deforestation occurred within oil palm concessions, resulting in $1.77 \mathrm{GtCO}_{2} \mathrm{e}(20.6 \%)$ of emissions; 1.44 Mha (12.6\%) of deforestation occurred within timber concessions, resulting in $1.30 \mathrm{GtCO}_{2} \mathrm{e}(15.1 \%)$ of emissions, and this literature also estimated that every additional $\$ 100$ per hectare per year in potential agricultural revenue increased the rate of deforestation by an average of $1.02-1.18 \%$, all else equal [17]. Report from CIFOR indicates that around the range between $60 \%$ to $80 \%$ of all deforestation in Indonesia is illegal [18].

In parts of Indonesia such as Sulawesi and Central Sumatra, cocoa is responsible for the opening up of primary forests and the establishment of settlements in these previously forested 
areas [19]. Full-sun cocoa, which increases the fragmentation of primary forests and is considered agriculturally unsustainable, is becoming common in Indonesia. Studied a village in Sulawesi where cocoa had been introduced in sloped uplands with short-term success. $82 \%$ of farmers interviewed had planted their cocoa on old crop fields or former agroforestry-based (coffee and fruit trees) farmland; only 5\% had cleared primary forest to plant cocoa. These farmers are choosing full sun cultivation due to landscarcity (partially a result of a national park designation) and the need to intercrop cocoa with sun loving food crops. Some farmers planted Gliricidiasepium to provide provisional shade for seedlings but otherwise the cocoa was allowed to grow without shade. The case of Sulawesi is instructive for several reasons. Much of the growing areas are on steep uplands within fertile soils with 3000-4000 m manual precipitation. These conditions can be linked to high rates of soil erosion, decomposition rates and water run off, and the prospects of sustainable sun grown cocoa is low without inputs especially if they suffer droughts [20]. The literature suggests that most cocoa growing regions have at one time or another experimented with full sun cultivation and that sooner or later they all have to return to a modicum of shade and agroforestry practices to rebuild ecological resources and renovate cocoa productivity. In Côte d'Ivoire, conclude that two to three generations of full sun cocoa cultivation has caused considerably more environmental damage than shade farming would have and that it may have had negative effects on rainfall patterns and overall ecosystem functioning [21].

The growing area of cocoa plantation in Indonesia in the past is mainly come from the expansion of forest area with cutting and burning method by the farmers. The effect of this expansion resulting loss of carbon sequestration. Deforestation due to the agriculture expansion area is the main problem which has affected global climate change in the world The global climate change has affected cocoa production in Indonesia, especially the effect of El-Nino in Eastern Indonesia as the center of cocoa plantation such Sulawesi Island. As the consequences of deforestation due to the expansion of forest area into full sun system of cocoa farming system in Indonesia resulting in increased temperatures and variable rainfall pattern are also making it difficult to establish new cocoa farms [22]. Reduced rainfall and increased temperatures, which lead to prolonged periods of drought, are causing a reduction in soil moisture during the dry seasons and decreased soil fertility. These conditions often lead to cocoa seedling mortality. In other areas and during periods of high rainfall, soil fertility is also negatively impacted by increased leaching of the soils and the lack of farmers applying fertilizer to replace nutrients. This is exacerbated in areas where farmers grow cocoa without shade [23]. According to Oyekale, prolonged dry seasons result in cocoa seed mortality, whereas short dry seasons result in decreased pod filling, which affect the size of the beans. Increased rains and prolonged wet seasons slow the drying and processing of cocoa, which reduces the value of the bean and increases the cost of processing both financially and the time required [24]. ICCO describe extreme weather to include weather phenomena that are at the extreme of the historical distribution, especially severe or unfavorable weather, they noted that temperature and rainfall are important factors that impacts on optimum yield [25]. Also, the amount of sunlight falling on the cocoa tree will affect its growth and yield, the most marked effect of humidity on cocoa is on the leaf area, the other effects of humidity concern the spread of fungal diseases and the difficulties of drying and storage of the product. Incessant rainfall for several weeks easily leads to wide spread of black pod disease which is very contagious also this poses untold hardship to the farmers because it drastically reduce the yield [26].

Precipitation, which appears to be the dominant driver in cocoa success, has the greatest impact inconcert with changes in temperature. For example, notes that hightemperatures in humid tropical areas such as in Malaysia are ideal growing conditions for cocoa; however, production suffers when decreased water availability due to elevated evapotranspiration or drought conditions coincide with higher temperatures [27]. Moreover, insufficient rainfall and increasing variability severely affected the West African and Sahelian regions' cocoa production during the 1970's and 1980 's. While studies have demonstrated that rain fall and humidity have the strongest impacts on cocoa production, on the other end of the spectrum, pathogens such as black pod disease (a major culprit of cocoa yield decline) reaches its highest prevalence following high rainfall and cool temperatures $[24,28]$. Beyond the biophysical constraints that cocoa production faces, changes in climate will also likely have considerable impacts on other stages in the chocolate supply chain. Moreover, climate changes affect the three phases of cocoa production seedling, establishment, and processing in different ways. For example, cocoa seedlings are particularly vulnerable to drought. Water deficit can lead to low yields, and prolonged rains can hinder the drying and processing of cocoa beans, leading to post-harvest losses [27, 28].

\section{Full Sun System and Cocoa Agroforestry System}

Cocoa cultivation practices that maintain higher proportions of shade trees (cocoa agroforestry) are increasingly being viewed as sustainable and environmentally preferable to other forms of agricultural activities in tropical forest regions [29]. A higher shade (from 30\% canopy cover) cocoa farm with improved management practices can be viewed as a sustainable agroforestry system that stores significant quantities of carbon on the farm [30]. Increasing productivity through the reduction of shade and an increase in the use of chemical inputs may ultimately decrease the economic security of small farmers. Therefore, shade provides many ecological benefits and once removed, farmers become dependent on chemical inputs that may not always be affordable to them. Improving cocoa yields does not require the use of full-sun and agrochemicals, rather increases in labor inputs such as regular pruning can reduce pests and increase yields [31]. 
Many observers see agroforestry systems as presenting a promising alternative to common-practice agriculture in the tropics because they can serve as carbon sinks and biodiversity pools and may play a significant role in mitigating or adapting to climate change [32-34]. A literature review indicated high potential for carbon sequestration in agroforestry systems, especially in the humid tropics. However, agroforestry's capacity for carbon sequestration remains underappreciated and underexploited because of a lack of consistent assessments and comparable data on carbon stocks and carbon cycles [34]. At the same time, there have been many studies on the environmental benefits of agroforestry systems in the tropics $[35,36]$. The sustainable production of cocoa plays a pivotal role for sustainable development, including poverty reduction in Indonesia. The use of production landscape in Indonesia for cocoa production has intensified dramatically over the last three decades. Indonesia is the one of the country which has experienced significant forest loss through the movements of the timber sector, oil palm expansion and expansion of the cocoa industry by promotion of zero shade cocoa production system or full sun system. This has gradually led to the fragmentation of forest landscapes, loss of wildlife corridors and forest connectivity, and degradation of biodiversity and the ecosystem goods and services these ecosystems offer. One of the prominent consequences of deforestation, which has significantly affected cocoa production, is a significant loss of soil nutrients. This has been one of the leading causes of the gradual decline of national cocoa yields in Indonesia [36].

Cocoa agroforestry has been described as one of the best examples of permanent agriculture that preserves a forest environment and also supports higher levels of biodiversity than most other tropical crops [37]. With exploitation of forest trees for timber and other purposes, it has become necessary to plant alternative fast growing tree species to provide shade, thus cocoa cultivation is of great importance for the cultivation of the forest and the associated fauna in Indonesia as the tropical country. Cocoa is either grown in low production systems under shade of other vegetation or in intensive production systems where trees are completely exposed to sunlight. With varying effect of fertilizer on cocoa yield on the two production system, the researcher further explained that fertilization of shade cocoa commonly produces only modest yield increments whiles the fertilization of sunlight-exposed plantations generally results in significant yield responses because of greater photosynthetic activity [38] This current trend of cocoa production (see figure 1) is making cocoa farming in Indonesia over time unproductive and degraded systems without the heavy application of chemical inputs, putting the long term future of cocoa farming, and farmers related rural livelihoods in Indonesia in some doubt.

Farmers and policy-makers face trade-offs between shorter-term economic maximization and long-term ecological sustainability. The trade-offs exist between an intensification of the cocoa cultivation with no shade plantations and higher economic returns and shade-grown, low intensity management cocoa with lower returns and biodiversity conservation [39]. Whether a particular cocoa production system is considered economically and ecologically sustainable it is affected by the time scale [40]. A recent study reported that the cocoa agroforestry contains 116 plant species as against 160, 171 and 64 in the primary forest, in the secondary forest, and on farmland respectively [41]. The production of cocoa under cocoa agroforestry systems can result in higher prices for the cocoa produced since buyers are willing to pay a premium for a products that is produced in a more environmentally sustainable manner, this assure a sustainable income for the producers under cocoa agroforestry system. Previous study indicated that due to the current state of the cocoa landscape, the best possible environmental alternative to the current cocoa-growing practices in Ghana would be a mixed agroforestry system, where the forest is selectively thinned and fruit trees with economic value are grown next to cocoa trees, providing both shade for the cocoa trees and food and income for the farming household [42].

A full sun system as no shade system is common in Indonesia which has no shade trees and management under this system is very intensive with use of agrochemicals input as well as labor making. Although it is capital intensive the associated yield is high in the early years of production, followed by a sharp fall in yield as compared to the other cocoa agroforestry systems [43]. A recent study in Cameroon revealed that $768 \mathrm{~kg} / \mathrm{ha}$ of cocoa can be obtained under direct sun as against 258 to 445 under shade [44]. Under the current cocoa landscape in Ghana, Ghana has 42 percent of its cocoa under the low shade system. This system is characterized by intensive management but not as intensive and input demanding as that of the no shade system. Ghana's cocoa landscape is currently made up of 25 percent medium shade [45]. Income from shade trees and other intercrops in cocoa agroforestry systems in Central Sulawesi (Indonesia) accounts for averagely about 7 percent of total cocoa plot revenue, but may reach up to 60 percent for mixed agroforestry plots [46]. Cocoa agroforestry systems also promote self-sufficiency through a diversified food-and-cash crop livelihood strategy [47]. Cocoa under shaded systems in Ghana can produce for over 70 years stated that cocoa agroforestry systems make a significant contribution to carbon sequestration indicating that cocoa agroforestry have considerable potential to sequester carbon in soils [48]. Findings from Indonesia on the amount of carbon under various cocoa agroforestry systems indicated that above-ground plant biomass was significantly lower in agroforestry with reduced canopy cover, mainly due to the removal of large trees [49]. He further stated that this reduction corresponds to a loss in above ground carbon storage of roughly $100 \mathrm{t} \mathrm{C}$ ha-1 via conversion of mainly undisturbed natural forest into low-shade agroforestry systems. The current trend of no shade is now common in cocoa growing countries like Cote d'Ivoire, Malaysia, Indonesia and Ecuador. In Ecuador half of the new cocoa being planted is now of the full-sun and are from the high-yielding variety [50]. Now in Sulawesi reveals that cocoa farmers are switching from long-fallow shifting cultivation of food crops to intensive full-sun cocoa. 


\section{Driving Sustainable Intensification on Cocoa Production Under Climate Change}

\subsection{The Concept of Sustainability}

Agricultural intensification is usually defined as a process of raising land productivity over time through increases in inputs on a per unit area basis $[51,52]$ within the context of the prevailing social and economic drivers [53]. Generally viewed, agricultural intensification may lead to changes in cropping regimes, which result in altered agro-ecosystems. These modified systems often display a reduced genetic and species diversity. This makes them more susceptible to exogenous shocks or environmental changes due to a lower adaptive capacity $[54,55]$. Early intensification theories suggest that switching from extension of crop area to production intensification may not be profitable for a farmer until beginning scarcity of land and/or ecosystem services is constraining land extension [55]. The induced intensification thesis explains changes in agricultural intensity by variations in farmer's behavior concerning production goals and rules of labor and capital allocation [56].

In order to meet the critical triangle goals, 'sustainable agricultural intensification' is widely being discussed as a potential solution. Sustainable intensification refers to an increase of agricultural production with a simultaneous maintenance or enhancement of the natural resource base [57]. This is to be achieved by a combination of adequate technologies, policy incentives and institutional reforms which are suitable for bringing in line the short term welfare objectives of farmers with long-term regional sustainability criteria that sustainable intensification aims at providing land use solutions that balance the preservation of forests, the livelihood needs of inhabitants and the growth requirements of regional and national policy makers [58, 59]. However, sustainable agricultural practices are frequently knowledge-intensive and thus require proper investments for development and dissemination. Agroforestry are generally deemed to provide opportunities for a sustainable intensification [59, 60]. Sustainability in agriculture is a complex and dynamic concept that includes a widerange of environmental, resource-based, economic, and social issues. This paper has no space to discuss a sharp dichotomy between unsustainable or sustainable farming systems because all types of farming can potentially contribute to achieving different sustainability goals and objectives. Ultimately, this paper suggest that sustainability is best evaluated against a range of environmental, economic, and social goals that reflect the views of diverse groups in society. According to National Academy of Science we found four key societal sustainability, viz [61]:

1. Satisfy human food, feed, and fiber needs, and contribute to biofuel needs.

2. Enhance environmental quality and the resource base.

3. Sustain the economic viability of agriculture.

4. Enhance the quality of life for farmers, farm workers, and society as a whole

The sustainability of a farming practice or system could be evaluated on the basis of how well it meets various societal goals or objectives. To be sustainable, a farming system needs to be robust (that is, be able to continue to meet the goals in the face of stresses and fluctuating conditions; to adapt and evolve), be sufficiently productive, use resources efficiently, and balance the four goals. Toward sustainability those goals need more specific objective that can achieve the goal that represent different paths toward sustainability. For instance, farming practices that produce the cocoa beans at a price that consumers can afford, and marketing and distribution systems to ensure that people have ready access to farm products. The concepts of productivity, affordability, and access represent specific objectives that are required to meet the overall goal of sustainability.

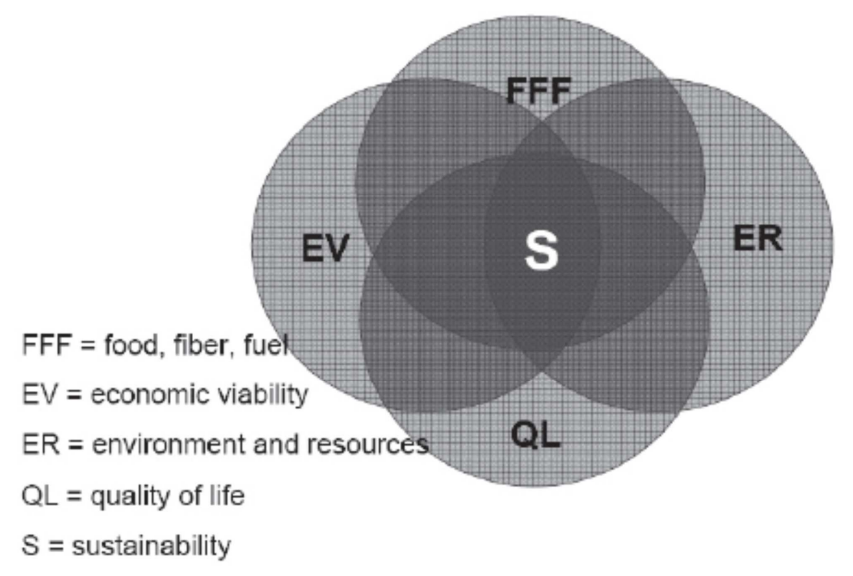

Source: Adopted from [61].

Figure 3. The Area where the four goals overlap represents the highest sustainablity in the continuum.

\subsection{Sustainable Intensification Under Climate Variablity}

Today climate change is projected to affect agriculture and natural ecosystem around the world, and many current farming practices damage the environment and are a major source of greenhouses gases (GHG). Besides, demand for food is increasing as population growth and gain wealth to purchase more varied and resource-intensive diets. These challenges require action throughout the food system. To increase food production from existing farmland in ways that place far less pressure on the environment and that do not undermine our capacity in order to continue producing food in the future, this call "sustainable intensification" whith four premises underlying Sustainable Intensification (SI): (1) increasing production to meet food demand efectively under climate change which has to respond to future increases in demand that should be environmentally sustainable [62]; (2) land expansion should be increased production but environmentally friendly with considering ecosystem services [63]; (3) Increasing food production should consider with environmental impacts. For instance in Indonesia paddy farming system has been pushed into three times planting of rice in a year (normally planting season only in the wet and 
dry season) with full chemical fertilizer and using chemical pesticide in order to meet the food self-sufficiency. This situation in Indonesia demands radical rethinking of food production to achieve major reductions in environmental impact to ensure sustainability and it should deliver the benefits to the environment such as wildlife conservation, carbon storage, flood protection, and also recreation; (4) Finally, sustainable intensification systems should have a specific goals and how it should be deployed. The merits of diverse approaches-conventional, "high tech," agro-ecological, or organic should be rigorously tested and assessed taking into account biophysical and social context in the society.

The main objective of sustainable intensification is to provide sufficient, accessible, nutrious food while enabling economic and social development in rural areas, and treating people, animals and the environment with respect [63]. Depending on the context, sustainable intensification on cocoa farming practices in Indonesia may mean increased profitability and productivity of cocoa beans with high efficiency and returns from external inputs, improved crop yield stability, reduced greenhouses gas emission, enhanced ecological resilience, better animal welfare, and environmental service provision (e.g., clean water, flood protection, recreational and cultural landscape). Simply speaking, sustainable agricultural intensification of cocoa bean aims to reduce the environmental foot print of cocoa production that requires making farming more precise by implementing genetic, agro-ecological, as well as socio economic intensification measures and having the necessary support systems in place for maximum impact (Figure 4).

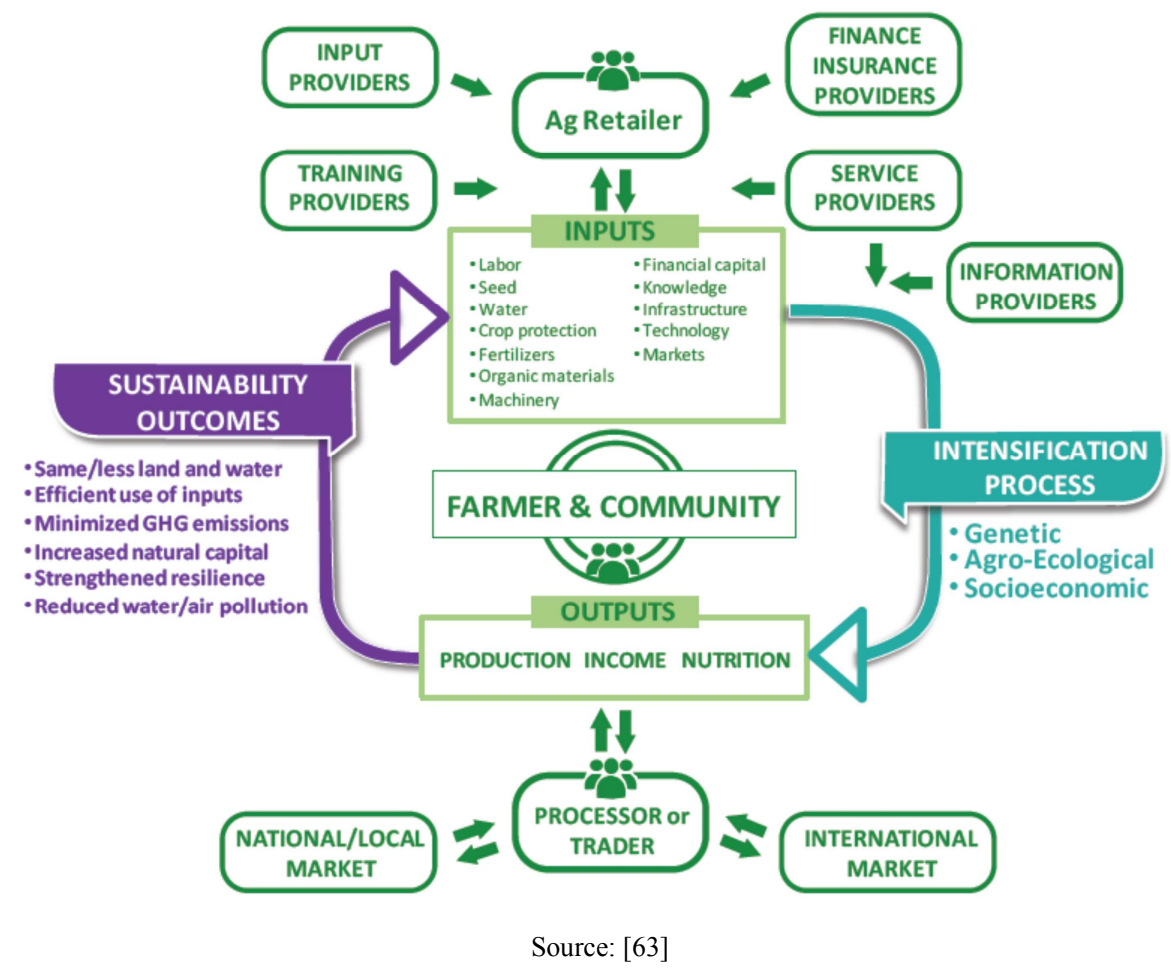

Figure 4. Sustainable Agricultural Intensification and its enabling environment.

Current farming practices worldwide are characterized by two intensification pathways, one based on high inputs and the other using natural processes [64]. The first system exemplified by the 'Green Revolution' has been successful in terms of agricultural productivity on a global scale, but it has also been accompanied by soil degradation, biodiversity declines and environmental pollution, with negative feedbacks on food security and farm incomes at local scales $[65,66]$. The second approach brings back traditional wisdom, combined with advances in ecological science into farm management, to achieve desired yields using more ecologically friendly intensification pathways [67]. Prior to the 'Green Revolution', the majority of subsistence farming anywhere in the world involved mixed species, usually including tree products [68]. Pressures towards higher efficiency drove modern agriculture into monocultures; the narrative of the green revolution in developing countries largely followed suit. But in the background, subsistence agroforestry systems have continued. As research has increasingly recognized the need to encompass ecosystems services other than food production, agroforestry has returned to the limelight. But this needs to inform understanding for the future, in terms of managing the climate but also other social and environmental changes. Agroforestry can help meet a variety of climate challenges, but will also be affected by climate change [69]. It can contribute in various ways to mitigation and adaptation to climate change [70]. For example in mitigation, agroforestry can contribute directly to effective, efficient and equitable REDD+, though perhaps best as a part of complementary landscape-level actions [71]. In terms of adaptation, trees and 
agroforestry seem to enhance the resilience of smallholder farmers to climate impacts because of their ability to perform both biophysical and socio-economic roles. Indeed, the environmental services provided by agroforestry mean that its adaptation potential extends well above the farm level. Yet, there will be other changes to contend with where agroforestry can help. For example, coupled with climate change, growth in demand for commodities will accelerate intensification [64] but intensification through agroforestry can help address some of the drivers of deforestation [71]. In light of the high potential of agroforestry for food security [72], climate change adaptation and mitigation, tree-based agricultural systems are currently being promoted in many parts of Africa [72], and they have successfully been established in many regions [73].

In Indonesia, cocoa is an important cash crop and the primary source of income of thousands of smallholder farmers in the lowland tropics. While the demand for cocoa in chocolate manufacturing countries is growing rapidly [74], cocoa producing regions suffer from dwindling yields and decreases in quality [75]. This reduces smallholder opportunities to maximize their revenues and threatens the sustainable sourcing of cocoa for the chocolate industry. Efforts by farmers to intensify production often include the reduction of shade tree cover in cocoa agroforestry systems [76]. While this provides farmers with short-term positive effects on yields, the removal of trees may lead to negative long term effects on crop production, resilience to climate change, and ecosystem service delivery $[35,36,49,77,78$, 79]. Aware of the risk of a future cocoa shortage, the cocoa industry has been increasingly promoting the cultivation of cocoa in agroforestry systems, which have the potential to improve ecosystem processes and functioning, and achieve long-term production, but might come at the expense of lower short-term yields $[49,79]$. However, there is likely to be some compromise between intensification efforts and the inclusion of trees that allows for numerous advantages due to beneficial roles of trees (i.e. soil aggregation, carbon sequestration, nutrient and water safety-net function) and optimizes production in both the short- and long-term. Smallholder agroforestry, such as cacao agro-ecosystems, offer the opportunity to combine high agricultural yield and high biodiversity goals on-farm [49, 79]. A recent study from Indonesia [36] shows that unshaded systems further increased income by $40 \%$, implying that current economic incentives and cultural preferences for new intensification practices put shaded systems atrisk. This study concludes that low-shade agroforestry provides the best available compromise between economic forces and ecological needs.

\section{Conclusions}

Generally speaking, we suggest that sustainable intensification in cocoa agroforestry provides many benefits of farming practices to strengthen rural communities, improve smallholders livelihoods and employment, and avoid negative social and cultural impacts and where sustainability objectives (e.g. GHG mitigation or biodiversity protection) require actions that need to be pursued to reduce resource intensive consumption and waste and to improve governance, efficiency and resilience for agriculture sustainable intensification on cocoa production. Evidence from agroforestry indicates that in this way, productive and environmentally friendly farming systems that provide food and nutritional security, as well as poverty alleviation, can be achieved in harmony with wildlife.

To be sustainable in order to meet cocoa demands in the world as the third largest cocoa producing country in the world, intensification system on cocoa farming practices in Indonesia should combine between modern agriculture and local wisdom into farm management with considering environmental aspects which provides ecosystem services, shaded system, implementing genetic with respond to climate change, and use resources efficiently and returns from external inputs that should taking into account biophysical and social context in the society. Simply speaking, sustainable intensification should meet productivity, profitability, feasibility, environmentally friendly, and compromise social economic forces.

\section{References}

[1] Vervoort J, Philip K. Thornton, Patti Kristjanson, WiebkeFo, Polly J. Ericksen, Kasper Kok, John S. I. Ingram, Mario Herrero, Amanda Palazzo, Ariella E. S. Helfgott, Angela Wilkinson, PetrHavlı, Daniel Mason-D'Croz, \& Chris Jost., Challenges to scenario-guided adaptive action on food security under climate change. Global Environmental Change, 1264, pp. 1-12, 2014. http://dx.doi.org/10.1016/j.gloenvcha.2014.03.001

[2] Wheeler, T \& Von Braun., Climate change impacts on global food security. Science, 341, pp. 508-513, 2013. http://Doi: 10.1126/science. 1239402 .

[3] IPCC (Intergovermental Panel Climate Change). The Fifth Assessment Report. Climate Change 2014: Impacts, adaptations and vulnerability. Cambridge University Press, Cambridge, United Kingdom and New York, NY, USA, pp. 1-32, 2014.

[4] Indonesian's Ministry of Agriculture. Grand Strategy 2015-2019, 2015. (In Bahasa).

[5] Indonesia's Center of Statistical Bureau. Statistic of Indonesia, 2015. (In Bahasa).

[6] FAOSTAT. Statistic of Cocoa Production in The World (2003-2013), 2014.

[7] Indonesia's Cocoa Association. Future of Growing Cocoa in Indonesia, 2015. (In Bahasa).

[8] ICCO. International Cocoa Organization's Quarterly Bulletin of Cocoa statistic, 2013.

[9] PISAgro. PISAgro News. A Quaterly News Letter. Partnership Support Sustainable FoodProduction. October, 11, 2015.

[10] IPCC (Intergovermental Panel Climate Change). The Fourth Assessment Report. Climate Change 2007: Impacts, adaptations and vulnerability. Cambridge University Press, Cambridge, United Kingdom and New York, NY, USA, pp. 1-32, 2014. 
[11] FAO. The State of the Food and Agriculture. Chapter 2. World food and agriculture in review. VialedelleTerme di Caracalla, 00153 Rome, Italy, pp. 63-81, 2011.

[12] Margono B. A. Advancing indonesian forest resource monitoring using multi-source remotely sensed imagery. Dissertation of Ph.D. Graduate School of The University of Maryland. College Park, 2014.

[13] M. C. Hansen, P. V. Potapov, R. Moore, M. Hancher, S. A. Turubanova,A. Tyukavina, D. Thau,S. V. Stehman, S. J. Goetz, T. R. Loveland, A. Kommareddy, A. Egorov, L. Chini, C. O. Justice, J. R. G. Townshend. High Resolution Global Maps of 21 st-Century Forest Cover Change. Science, 342, pp. 850-853, 2013.DOI: 10.1126/science.1244693.

[14] FAO. Global Forest Resources Assessment. VialedelleTerme di Caracalla, 00153 Rome, Italy, pp. 378, 2010.

[15] RAN (Rainforest Action Network). Report: Lesson from the incencsefores, 2015. http://www.ran.org/incenseforest

[16] Van der Werf, D. C. Morton, R. S. DeFries, J. G. J. Olivier, P. S. Kasibhatla, R. B. Jackson, G. J. Collatz and J. T. Randerson. $\mathrm{CO}_{2}$ emission from forest loss. Nature Geoscience, 2, pp. 737-738. 2009.

[17] Jonah B, KalifiFerretti-Gallona, Jens Engelmanna, Max Wrightb, Kemen G. Austinc,d, Fred Stollec, Svetlana Turubanovae, Peter V. Potapove, Belinda Margonoe, Matthew C. Hansene, and Alessandro Baccinif. Reduction in emission from deforestation form Indonesia's Moratorium on new palm oil, timber, and logging consession. Proceeding National Academy of Science, 112, pp. 1328-1333, 2014. www.pnas.org/cgi/doi/10.1073/pnas

[18] CIFOR. Generating Economic Growth, Rural Livelihoods, and Environmental Benets fromIndonesias Forests: A Summary of Issues and Policy Options. Center for International Forestry Research, report prepared for the World Bank, 2004.

[19] Franzen M and Mulder M. B. Ecological, Economic and Social Perspectives on Cocoa Production Worldwide. Biodiversity Conservation, 16, pp. 3835-3849, 2007.

[20] Belsky JM, Siebert SF. Cultivating Cacao: implications of sun-grown cacao on local food security and environmental sustainability. Agriculture andHuman Values, 20, pp. 277-285, 2003.

[21] Ruf, F. and Schroth, G. Chocolate forests and monocultures: a historical review of Cocoa growing and its conflicting role in tropical deforestation and forest conservation. Agroforestry and Biodiversity Conservation in Tropical Landscapes (Eds G. Schroth, G. A. B. Da Fonseca, C.A. Harvey, C. Gascon, H. L. Lasconcelos\&A. N. Izac), pp. 107-134., 2003. Island Press, Washington, DC.

[22] Hutchins A, Tamargo A, Bailey C and Kim Y. Assessment of Climate Change Impacts on Cocoa Production and Approaches to Adaptation and Mitigation: A contextual View of Ghana and Costa Rica. World Cocoa Foundation, 2015.

[23] Anim-Kwapong, G. J. and Frimpong, E. B. Vulnerability of Agriculture to climate change impact of climate on cocoa production. Cocoa Research Institute, New TafoAkim, Ghana, 2005.

[24] Oyekale, A. S., Bolaji, M. B. \& Olowa, O. W. The Effects of Climate Change on Cocoa production and Vulnerability Assessment in Nigeria. Agricultural Journal, 4, pp. 77-85, 2009.
[25] ICCO. International Cocoa Organization's Quarterly Bulletin of Cocoa statistics. 2003. http://www.icco.org/about-us/international-cocoa-agreements/ cat_view/1-annual-report.html

[26] Ajewole Davies Ojo and IyandaSadiq. Effect of climate change on cocoa yield: a case of cocoa research institute (CRIN) farm, Oluyole local government Ibadan Oyo State. Journal of Sustainable Development in Africa, 12, pp. 350-358, 2010.

[27] Laderach, P., Martinez-Valle, A., Schroth, G. \& Castro, N. Predicting the future climatic suitability for cocoa farming of the world's leading producer countries, Ghana and Côte d'Ivoire. Climatic Change, 119, pp. 841-854, 2013.

[28] Oluyole, K. A., Emaku, L. A., Aigbekaen, E. O., \& Oduwole, O. O. Overview of the trend ofclimate change and its effect on cocoa production in Nigeria. World Journal of Agricultural Research, 1, pp. 10-13, 2013.

[29] UNDP. Environment Sustainability and Policy for Cocoa Production in Ghana. COCOBOD, pp 56, 2012.

[30] Katoomba. Transition. 2009. www.transitionkatoomba.org.au/transition towns.htm

[31] Clay, J. World agriculture and the environment: A commodity-by-commodity guide to impacts and practices. Island Press, Washington, 2004.

[32] Tscharntke T, Clough Y, Bhagwat SA, Buchori D, Faust H, Hertel D, lscher DH, Juhrbandt J, Kessler M, Perfecto I, Scherber1 C, Schroth G, Veldkamp E, Wanger TC. Multifunctional shade-tree management in tropical agroforestry landscapes- review. Journal Applied Ecology, 48, pp. 619-629, 2010. doi: 10.1111/j.1365-2664.2010.01939.x.

[33] Soto-Pinto L, Anzueto M, Mendoza J, Jimenez Ferrer G, \& de Jong B. Carbon sequestration through agroforestry in indigenous communities of Chiapas, Mexico. Agroforestry System, 78, pp. 39-51, 2010.

[34] Nair PKR, Kumar BM, \& Nair VD. Agroforestry as a strategy for carbon sequestration. Journal of Plant Nutrition andSoil Science, 172 (1), pp. 10-23, 2009.

[35] Clough, Y., H. Faust, and T. Tscharntke. Cacao boom and bust: sustainability of agroforests and opportunities for biodiversity conservation. Conservation Letters 2, pp. 197-205, 2009.

[36] Tscharntke, and O. van Straaten. Effects of an experimental drought on the functioning of a cacao agroforestry system, Sulawesi, Indonesia. Global Change Biology, 16, pp. 1515 1530,2010

[37] Rice, R. A. and Greenberg, R. Cacao cultivation and the conservation of biological diversity. Ambio, 29(3) pp. 81-87, 2004.

[38] Uribe Armando, MÈndez Hernando, and MantillJairo. Effect of Balanced Fertilization on Cocoa Yield. Better Crops International, 15, pp. 53, 2001.

[39] Seeberg-Elverfeldt C., Schwarze S., \& Zeller M. Payments for Environmental Services - Incentives through Carbon Sequestration Compensation for Cocoa-based Agroforestry Systems in Central Sulawesi, Indonesia. International Journal of the common, 3, pp. 108-130, 2009. http://doi.org/10.18352/ijc.96 
[40] Baah F., Anchirinah V., and Badu-Yeboah A. Perceptions of extension agents on information exchange with cocoa farmers in the Eastern region of Ghana. Scientific Research and Essay, 4, pp. 694-699, 2009.

[41] Zapfack L., Engwald S., Sonke B., Achoundong G., and Madong B. The impact of land conversion on plant biodiversity in the forest zone of Cameroon. Biodiversity Conservation, 11, pp. 2047-2061, 2002.

[42] Gockowski J, \& Sonwa, D. Cocoa intensification scenarios and their predicted impact on $\mathrm{CO}_{2}$ emissions, biodiversity conservation, and rural livelihoods in the Guinea Rain Forest of West Africa. Environmental Management, 8, pp. 307-321, 2010 doi: 10.1007/s00267-010-9602-3.

[43] Ruf, F. and Zadi H. Cocoa: from deforestation to reforestation. Paper from workshop on Shade Grown Cocoa held in Panama, 3/30-4/2, 1998. Smithsonian institution. Washington, D.C.

[44] Sonwa, D. J., Nkongmeneck, B. A., Weise, S.F., Tchatat, M., Adesina, A. A. and Janssens, M. J. J. Diversity of plants in cocoa agroforests in the humid forest zone of southern Cameroon. Biodiversity and Conservation, 16, pp. 2385-2400, 2007.

[45] UNDP. Greening the sustainable cocoa supply chain in Ghana http://greencommodities.org/index.php?option=com_content\& view $=$ article $\& \mathrm{id}=16 \&$ catid $=9 \&$ Itemid $=65$

[46] Juhrbandt, J. Economic valuation of land-use change - a case study on rainforest conversion and agroforestry intensification in Central Sulawesi, Indonesia. Doctoral thesis, Faculty of Agriculture, Georg-August University, Gottingen, 2015.

[47] Nunoo I. Financial viability of cocoa agroforestry systems in Ghana: The case of SefwiWiawso District. Master Thesis, Departement of Agriculture Economics, Agribusiness and Extension. Kwame Nkrumah University of Science and Technology, 2015.

[48] Obiri, B. D., Bright, G. A., McDonald, M. A., Anglaaere, L. C. N. and J. Cobbina. Financial Analysis of Shaded Cocoa in Ghana.Agroforestry Systems, 71, pp. 139-149, 2007.

[49] Steffan-Dewenter, I., Kessler M., Barkmann, J., Bos, M. M., Buchori D., and Erasmi, S. Tradeoffs between income, biodiversity, and ecosystem functioning during tropical rainforest conversion and agroforestry intensification. Proceeding National Academy of Science, 12, pp. 4973-4978, 2007.

[50] Bentley J.W, Boa E, Stonehouse J. Neighbor trees: shade, intercropping, and cacao in Ecuador. Human Ecology, 32, pp. 241-270, 2004.

[51] Shriar, A. Determinants of Agricultural Intensity Index "Scores" in a Frontier Region: An Analysis of Data from Northern Guatemala. Agriculture and Human Values,22, pp. 395-410, 2005

[52] Ellis, F. Rural Livelihoods and Diversity in Developing Countries. Oxford University Press, Oxford, 2000.

[53] Lambin, E. F., Turner, B. L., Geist, H. J., Agbola, S. B., Angelsen, A., Bruce, J. W., Coomes, O. T., Dirzo, R., Fischer, G., Folke, C., George, P. S., Homewood, K., Imbernon, J., Leemans, R., Li, X., Moran, E. F., Mortimore, M., Rama-krishnan, P.S., Richards, J.F., Skånes, H., Steffen, W., Stone, G. D., Svedin, U., Veldkamp, T. A., Vogel, C., $\mathrm{Xu}, \mathrm{J}$. The causes of land-use and Introduction, pp.43, 2001.
[54] Perrings, C. The economics of biodiversity loss and agricultural development in low-income countries. In: Lee, D. R., Barrett, C. B. (Eds.). Tradeoffs or synergies? Agricultural intensification, economic development and the environment, 2001. Wallingford, UK: CABI Publishing Co.

[55] Lee, D. R., Ferraro, P. J., Barrett, C. B. Introduction: Changing perspectives on agricultural intensification, economic development and the environment. In: Lee, D. R., Barrett, C. B. (Eds.). Tradeoffs or synergies? Agricultural intensification, economic development and the environment, 2001.Wallingford, UK: CABI Publishing Co.

[56] Turner, B. L., Ali, A. M. S. Induced intensification: Agricultural change in Bangladesh with implications for Malthus and Boserup. Proceedings National Academy of Sciences, 93, pp. 14984-14991, 1996.

[57] Ruben, R., Kuyvenhoven, A., Kruseman, G.Bioeconomic Models and Eco-regional Development: Policy Instruments for Sustainable Intensification. In: Lee, D. R., Barrett, C. B. (Eds.). Tradeoffs or synergies? Agricultural intensification, economic development and the environment, 2001. Wallingford, UK: CABI Publishing Co.

[58] Tilman, D., Cassman, K. G., Matson, P. A., Naylor, R., Polasky, S. Agricultural sustainability and intensive production practices. Nature, 418, pp. 671-677, 2002.

[59] Gockowski, J. and Sonwa, D. Biodiversity and Smallholder Cocoa Production Systems in West Africa, STCP Working Paper Series Issue 6, 2008.Available online at www.treecrops.org

[60] Tomich, T. P., Van Noordwijk, M., Budidarseno, S., Gillison, A., Kusumanto T., Murdiyarso, D. Stolle, F., Fagi, A.M. Agricultural intensification, de-forestation, and the environment: assessing tradeoffs in Sumatra, Indonesia. In: Lee, D. R. a. B., C. B. (Eds.), Tradeoffs or synergies? Agricultural intensification, economic development, and the environment, pp. 221-244, 2001.Wallingford, Oxon, UK. CAB International.

[61] NAS. National Academy of Sciences. Toward Sustainable Agricultural System in the 21st century. Committee on Twenty-First Century System Agriculture. Board on Agriculture and Natural Resources Division on Earth and Life Studies, 2012. National Research Council of the National Academies. USA.

[62] Garnett T, M. C. Appleby, A. Balmford, I. J. Bateman, T. G. Benton, P. Bloomer, B. Burlingame, M. Dawkins, L. Dolan, D. Fraser, M. Herrero, I. Hoffmann, P. Smith, P. K. Thornton, C. Toulmin, S. J. Vermeulen,H. C. J. Godfray. Sustainable Intensification in Agriculture: Premises and Policies, Science, 341, pp. 33-34, 2013. http://dx.doi.org/10.1126/science. 1234485

[63] United Nations. Solutions for Sustainable Agriculture and Food Systems. Technical report for the post-2015 development agenda, 2013.

[64] Carsan M, Aldo Stroebel, Ian Dawson, Roeland Kindt, CheikhMbow, JeremiasMowo and RamniJamnadass. Can agroforestry option valuesimprove the functioning of drivers of agricultural intensification in Africa? Current Opinion in Environmental Sustainability, 6, pp. 35-40, 2014. http://dx.doi.org/10.1016/j.cosust.2013.10.007

[65] Keating, B. A., Carberry, P. S., Bindraban, P., Asseng, S., Meinke, $\mathrm{H}$. and Dixon, J. Eco-efficient agriculture: concepts, challenges and opportunities. Crop Science, 50, pp. 109-119, 2010. http://crop.scijournals.org/cgi/reprint/50/Supplement 1/S-109. 
[66] Flynn DFB, Gogol-Prokurat M, Nogeire T, Molinari N, Richers BT.Loss of functional diversity under land use intensification across multiple taxa. Ecology Letter, 12, pp. 22-33, 2009. doi:10.1111/j.1461-0248.2008.01255.x.

[67] Leakey RRB. Agroforestry: a delivery mechanism for multifunctional agriculture. 2009. Nova Publications, James Cook University, Cairns.

[68] Mbow C, van Noordwijk M, Luedeling E, Neufeldt H, Minang PA, Kowero G. Agroforestry solutions to address food security and climate change challenges in Africa. Current Opinion in Environmental Sustainnability, 6, pp. 61-67, 2014. doi:10.1016/j.cosust.2013.10.014.

[69] Luedeling E, Huth NI, Kindt R, Konig K. Agroforestry systems in a changing climate challenges in projecting future performance. Current Opinion in Environmental Sustainnability, 6, pp. 1-7, 2014. doi: 10.1016/j.cosust.2013.07.013.

[70] Mbow C, Smith P, Skole D, Duguma L, Bustamante M. Achieving Mitigation and Adaptation to climate change through sustainable agroforestry practices in Africa. Current Opinion inEnvironmentalSustainnability, 6, pp. 8-14, 2014. doi: 10.1016/j.cosust.2013.09.002.

[71] Minang PA, Duguma LA, Bernard F, Metz O, van Noordwijk M. Prospects for Agroforestry in REDD+ landscapes in Africa. Current Opinion in Environmental Sustainnability, 6, pp. 78-82, 2014. http://dx.doi.org/10.1080/14693062.2014.912979

[72] Garrity DP, Akinnifesi FK, Ajayi OC, Weldesemayat SG, Mowo JG, Kalinganire A, Larwanou M, Bayala J. Evergreen agriculture: a robust approach to sustainable food security in Africa. Food Security, 2, pp. 197-214, 2010. DOI 10.1007/s12571-010-0070-7.
[73] Sendzimir J, Reij CP, Magnuszewski P. Rebuilding resilience in the Sahel: regreening in the Maradi and Zinder regions of Niger Ecology and Society, 16 (3), pp. 1608, 2011. http://dx.doi.org/10.5751/ES-04198-160301

[74] Scrotch, G \& Harvey, C. A. Biodirversity conservation in cocoa production landscape: An Overview. Biodiversity Consevation, 16(8), pp. 2237-2244, 2007. DOI 10.1007/s10531-007-9195-1.

[75] Franzen, M \& Mulder, M. B. Ecological, economic and social perspektive on cocoa production worldwide. Biodiversity Consevation, 16 (8), pp. 3835-3849, 2007. DOI 10.1007/s10531-007-9183-5.

[76] DaghelaBisseleua HB, Fotio D, Yede, Missoup AD, Vidal S (2013) Shade Tree Diversity, Cocoa Pest Damage, Yield Compensating Inputs and Farmers' Net Returns in West Africa. PLoS ONE 8 (3), pp. 1-9, 2013. e56115. doi:10.1371/journal.pone.0056115.

[77] Wood, G. A. R. and R. A. Lass. pp.620, 2001. Cocoa. 4th edition. Blackwell Science, Oxford.

[78] Bos, M. M., I. Steffan-Dewenter, and T. Tscharntke. Shade tree management affects fruit abortion, insect pests and pathogens of cacao. Agriculture Ecosystems \& Environment, 120, pp: 201-205, 2007.

[79] Clough Y, Barkmann J, Juhrbandt J, Kessler M, Wanger TC, Anshary A, Buchori D, Cicuzza D, Darras K, Putra DD, Erasmi S, Pitopang R, Schmidt C, Schulze CH, Seidel D, Steffan-Dewenter I, Stenchly K, Vidal S, Weist M, Wielgoss AC, Tscharntke T. Combining high biodiversity with high yields in tropical agroforests. Proceeding National Academy of Science, 108 (20), pp. 8311-6, 2001. doi: $10.1073 /$ pnas. 1016799108 . 